\title{
Effect of Hydroxyzine in Controlling Acute Chemotherapy-Induced Vomiting in Children: A Randomised Trial
}

\author{
Nilgun KURUCU, Mursel DURMAZ \\ Karadeniz Technical University Faculty of Medicine, Departments of Pediatric Oncology, Trabzon, TURKEY
}

\begin{abstract}
ABSRACT
Nausea and vomiting are one of the most important side effects of chemotherapy. Psychological factors such as anxiety, fear and negative moods have significant role in the chemotherapy induced emesis. Each chemotherapy course cause state anxiety like an invasive medical procedure. Therefore, we aimed to evaluate the effect of addition a sedative-anxiolytic agent to a 5-HT3 receptor antagonist in improving the control of chemotherapy induced emesis. Seventy chemotherapy courses in 18 children who received at least one highly emotogenic drugs were interpreted. Courses were randomly assigned to receive ondansetron (group I) or ondansetron plus hydroxyzine as a sedative agent (group II). Control of emesis was evaluated according to Soukop-Smith criteria. Performance of patients and degree of symptoms was assessed by using Lansky Play-Performance Scale and the Symptom Distress Scale, respectively. The complete and major control rate of acute emesis in group II (56\%) was higher than group I (22\%) ( $p=$ 0.006). The effect of combination antiemetic therapy was more obvious in female than male $(p=0.03)$, and in patients whose age greater than 10 years $(p=0.02)$. The mean play performance scale and symptom distress scale score were similar in two groups, before the chemotherapy course. After completion of course, play performance and symptom distress scale score were significantIy better in group-II than that of group-I. Patients and parents in group-II declared significantly better sleeping quality, appetite, activity and mood than group-I. Hydroxyzine may enhance the activity of ondansetron in controlling acute chemotherapy-induced emesis and provided a better performance and lesser symptom distress.
\end{abstract}

Keywords: Chemotherapy, Emesis, Antiemetic agents, Sedative agents, Quality of life

\section{ÖZET}

\section{Kemoterapiye Bağlı Kusmanın Kontrolünde Hidroksizinin Rolü: Randomize Klinik Çalışma}

Bulantı ve kusma kemoterapinin en önemli yan etkilerinden biridir. Anksiyete, korku, negatif ruh hali gibi psikolojik faktörler kemoterapiye bağı kusmada önemlidir. Bu nedenle çalısmamızda, 5-HT3 reseptor antagonistlerine sedatif anksiyolotik ajan olarak hidroksizin eklenmesinin kemoterapiye bağlı emezisin kontrolündeki rolünün araştıııması amaçlanmıştır. Onsekiz hastaya uygulanan ve yüksek emotojen kemoterapötik ajan içeren 70 kür değerlendirildi. Kürler rastgele olarak ondansetron (grup I) veya ondansetron+ hidroksizin (grup II) grubuna dahil edildi. Emezisin kontrolü Soukop-Smith kriterlerine gore değerlendirildi. Hastaların performansı Lansky Oyun-Performans Skalası ile semptomların derecesi Semptom Distres Skalası ile değerlendirildi. Grup I'deki hastaların \%22'de, grupII'deki hastaların ise \%56'sında emezisin tam veya major kontrolü sağlanmıştır ( $p=0.006$ ). Kombinasyon antiemetik tedavinin etkinliği kızlarda erkelerden daha aşikardı ( $(p=0.03)$. Ondansetron+Hidroksizin kombinasyonu 10 yaş üstünde daha küçük çocuklara göre daha etkin kontrol sağlamaktaydı $(p=0.02)$. Kemoterapi kürü öncesinde iki grubun oyun performans ve semptom distress skalaları ortalama değerleri arasında önemli bir farklılık yoktu. Ancak kemoterapi kürü sonrasında ise her iki skalanın ortalama değerleri grupI'de grup I'den daha yüksekti. Hastalar ve aileleri tarafından bildirilen iştah, uyku kalitesi, aktivite ve ruh halinin grup-Il'de grup-l'den daha iyi olduğu belirlendi. Antiemetik tedavide hydroksizinin ile ondansetronun birlikte uygulanmasının emezisin kontrolünü arttırdığı ve daha iyi bir performans ve daha az semptom distres sağladığı belirlendi.

Anahtar Kelimeler: Kemoterapi, Emesis, Antiemetik ajanlar, Sedatif ajanlar, Yaşam kalitesi 


\section{INTRODUCTION}

Nausea and vomiting is one of the most frequent side effects of chemotherapy. Severe emesis may cause dehydration, metabolic problems, malnutrition and difficulty in maintaining daily activities. Optimal management of emesis is important for compliance with chemotherapy, adequate nutritional intake and the quality of life of patients. ${ }^{1,2}$ Currently available antiemetic drugs provide obvious benefits, but none is completely satisfactory especially for the highly emotogenic treatments. ${ }^{2,3}$ Chemotherapy induced emesis is a multifactorial, complex issue which is not obviated by drugs alone. Psychological factors such as anxiety, fear, negative moods, emotional labiality and stress can powerfully amplify chemotherapy induced emesis., ${ }^{2,4}$ Therefore we conducted a randomized prospective study to assess the efficacy of addition hydroxyzine (a histamine-H1 receptor antagonist) as a sedative-anxiolytic agent to ondansetron (a 5-HT3 receptor antagonist) in improving the control of chemotherapy induced emesis.

\section{PATIENTS and METHODS}

The study was conducted on children with cancer who were diagnosed and being treated in Department of Pediatric Oncology School of Medicine, Karadeniz Technical University. Chemotherapy courses including at least one level 5-4 (highly) emetogenic ${ }^{2,5}$ drug in children diagnosed with malignant disease were evaluated for control of nausea and vomiting. Patients whose ages were less than 2 years and who had tumor or any space occupying lesion in central nervous system, gastric ulcer, gastric obstruction, hepatic or renal dysfunction, cardiac failure and any accompanying disease causing emesis were not included in the study. The study was approved by institutional ethic committee, and informed consent has been taken.

Seventy chemotherapy courses in 18 newly diagnosed children were interpreted. There were eight female and ten male with mean age 115 \pm 53 (35-207) months. Diagnosis of patients were non-Hodgkin lymphoma in five patients, rhabdomyosarcoma in three, neuroblastoma in two, osteosarcoma in two, Ewing sarcoma family in two and other neoplasm in the remainder. Characteristics of cases and app- lied protocols are given in Table 1. Patients received the highly emetogenic drugs by continuous infusion for 1 to 120 hours. Chemotherapy courses were randomly assigned to receive ondansetron (group I) or ondansetron plus hydroxyzine (group II). Patients mignt have randomized to received the group I or group II drugs in different courses. Two patients were randomized on six occasions, four in five occasions, five in four occasions, four in three occasion and three were randomized twice.

Ondansetron (Zofran®, Glaxo Smith Cline) was administered $5 \mathrm{mg} / \mathrm{m}^{2} /$ dose intravenously $15 \mathrm{minu}$ tes before chemotherapy and continued two times a day throughout chemotherapy course. Hydroxyzine (Atarax ${ }^{\circledR}$, UCB Pharma) was given $1 \mathrm{mg} / \mathrm{kg} / \mathrm{dose}$ orally 12 hours and 30 minutes before the chemotherapy, and continued twice daily throughout chemotherapy course.

Nausea and vomiting were recorded by the same physician from beginning of chemotherapy to 24 hours after its end by interviewing patients, parents and by examining nurse observation record. The efficacy of antiemetic therapy was evaluated according to Soukop-Smith criteria. ${ }^{6,7}$ Patients who experienced no vomiting and no or only mild nausea accepted as complete responder. Patients who experienced just one episode of vomiting, or no vomiting with moderate to severe nausea accepted as major responder. Side effects attributed to ondansetron and hydroxyzine were also recorded.

The symptom distress and performance of patients was assessed by observing and interviewing with patients. Parents' opinion was also taken into consideration. The performance status of patients was measured by using Lansky Play-Performance scale. ${ }^{8}$ The Symptom Distress Scale (SDS) ${ }^{9}$ was used for obtaining symptoms occurrence and distress. This scale was developed by Mc Corcle and Young $^{10}$, and demonstrated high reliability and validity among cancer patients. ${ }^{11}$ Symptom distress scale has also been administered in children who received cancer treatment. ${ }^{12}$ This model emphasizes the difference between the occurrence of symptom and emotional response (distress) to its occurrence. Among 13-items of SDS including activity, appetite, insomnia, mood were evaluated and scored on 5 points ordinal scale; 1 indicating no problem with the symptom and 5 maximum amount of distress 


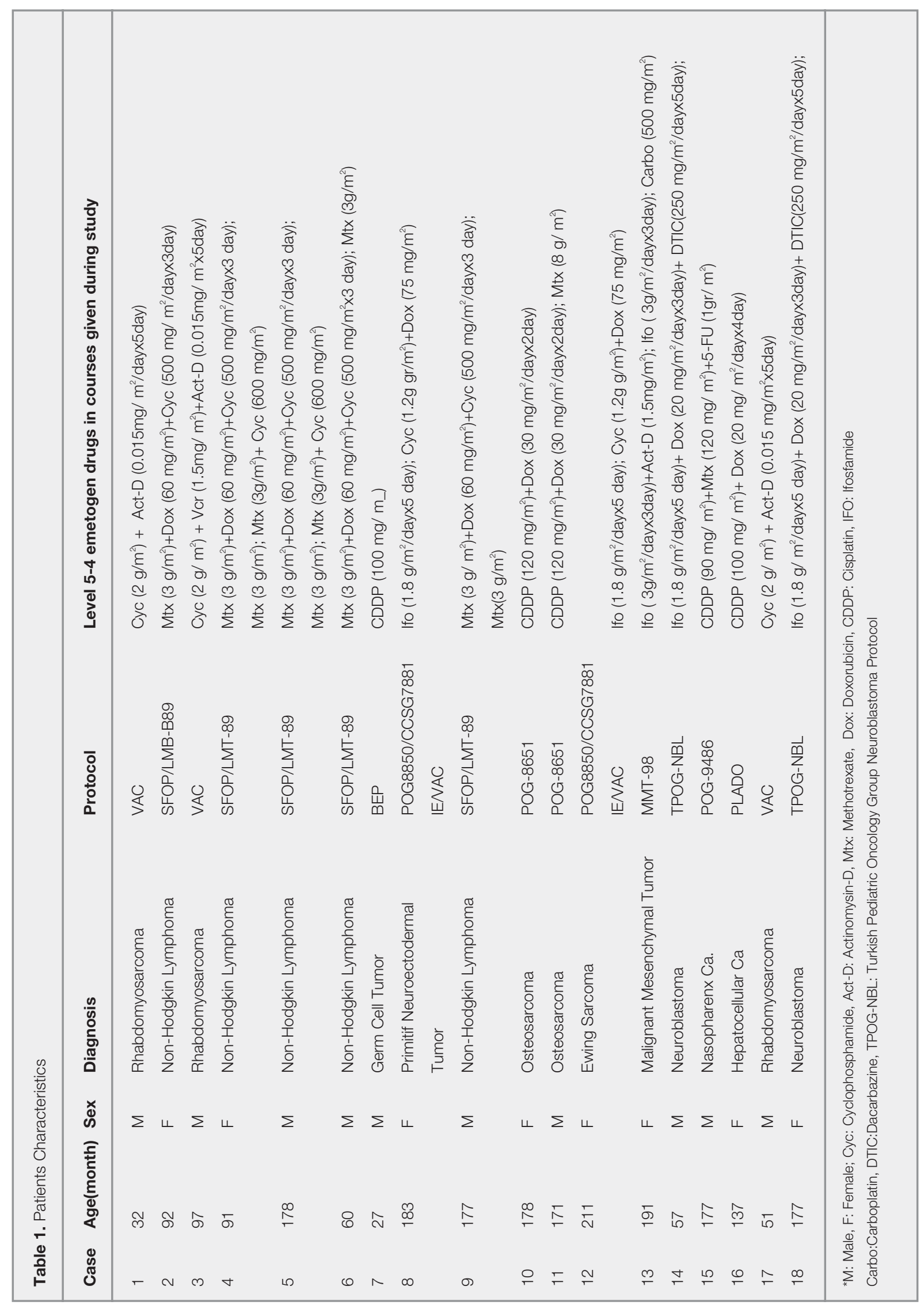


with the symptom. Total score are range from 13 to 65 ; higher scores reflect more severe symptomatology. Total SDS score $\geq 25$ reflects moderate to severe symptom problems.

Two groups were compared in context of control of emesis, performance and symptom distress scale. The effect of sex, age, histopathologic diagnosis and stage of malignancy, number and duration of chemotherapy course in controlling emesis were also evaluated. Independent samples t-test was used for comparison of mean values. Frequencies were compared with the continuity corrected chi-square or Fisher's exact test. ${ }^{13}$

\section{RESULTS}

Out of 70 chemotherapy courses 36 were randomly assigned to receive ondansetron (group I) and 34 were ondansetron plus hydroxyzine (group II). In group I, courses were given to 17 female and 19 male patients; while courses were given to 16 female and 18 male patients in group II. Twenty-four and 19 courses in group I and group II, respectively were given patients older than ten years. There was no statistical difference between the groups according to sex and age distribution ( $p>0.05$ ). The mean duration of treatment in 70 courses was $2 \pm 1.5$ (1-5) days. The duration of courses were three days or longer in $8(22 \%)$ and $9(26.5 \%)$ in group I and group II, respectively ( $\mathrm{p}>0.05)$.

The complete and major control rate of acute emesis in ondansetron plus hydroxyzine group was significantly $(\mathrm{p}=0.004)$ higher than group I (Table 2$)$. Combination therapy provided a better control in

\begin{tabular}{|c|c|c|}
\hline EMESIS & Group I & Group II \\
\hline Complete/Major response & 8 (22\%) & 19 (56\%) \\
\hline Minor/ No response & 28 (78\%) & 15 (44\%) \\
\hline Total & 36 & 34 \\
\hline
\end{tabular}

both sex but difference was significant $(\mathrm{p}=0.02)$ only in female (Table 3 ). The effect of combination of hydroxyzine with ondansetron was more obvious in patients whose age greater than 10 years $(\mathrm{p}=$ 0.004 ), while the difference was not so important in age $\leq 10$ years (Table 4). Complete and major control of emesis was significantly ( $\mathrm{p}=0.004)$ lower in group I than in group II, in courses continuing less than three days (Table 5). However in protocols which continue three days or more, the difference of control rate between two groups was not significant. Diagnosis and stage of disease and the number of course had not any effect on emesis.

Two anti-emetic groups were compared in context of performance and symptoms distress. The mean play performance scale of patients in total 70 courses were $70.5 \pm 10.4$ and $60.0 \pm 10.7$ respectively, before and 24 hours after completion of the chemotherapy course. There was no difference between the group I and group II in mean play performance scale before chemotherapy $(70.3 \pm 10.3$ and $70.6 \pm 9.9$;

\begin{tabular}{|c|c|c|c|c|}
\hline \multirow[t]{2}{*}{ EMESIS } & \multicolumn{2}{|c|}{ Male* } & \multicolumn{2}{|c|}{ Female $^{\star \star}$} \\
\hline & Group I & Group II & Group I & Group II \\
\hline Complete/Major response & $5(26 \%)$ & $10(55 \%)$ & $3(18 \%)$ & 9 (56\%)f \\
\hline Minor/ No response & $14(74 \%)$ & $8(45 \%)$ & $14(82 \%)$ & 7 (44\%) \\
\hline Total & 19 & 18 & 17 & 16 \\
\hline
\end{tabular}


Table 4. Control of emesis according to age group

\begin{tabular}{|c|c|c|c|c|}
\hline \multirow[t]{2}{*}{ EMESIS } & \multicolumn{2}{|c|}{ Age $\leq 10$ years ${ }^{\star}$} & \multicolumn{2}{|c|}{ Age $>10$ years $* *$} \\
\hline & Group I & Group II & Group I & Group II \\
\hline Complete/Major response & $5(42 \%)$ & $10(67 \%)$ & $3(13 \%)$ & $9(47 \%)$ \\
\hline Minor/ No response & 7 (58\%) & 5 (33\%) & 21 (87\%) & $10(53 \%)$ \\
\hline Total & 12 & 15 & 24 & 19 \\
\hline
\end{tabular}

$\mathrm{p}=0.36$ ). However, after completion of course play performance scale was significantly better in group II than group I $(60.3 \pm 10.3$ vs. $50.2 \pm 10.6, p=0.013)$. The mean symptom count was $1.5 \pm 1.8$ and $0.9 \pm 1.8$ in group I and group II, respectively $(\mathrm{p}=0.33)$ before chemotherapy courses. It was $5.7 \pm 2.5$ and $3.8 \pm 2.1$ in group I and group II, respectively ( $\mathrm{p}=$ $0.025)$ after chemotherapy. The mean total SDS score of group I and group II was similar before chemotherapy (14.8 \pm 2.1 and 14.2 \pm 2.9$)$. After chemotherapy courses, mean SDS score was better in group II (18.2 \pm 4.8$)$ than group I (21.4 \pm 5.8$)$, although the difference was not statistically significant $(p=0.07)$. When distress degree of each symptom was evaluated separately, there was no difference between two groups before chemotherapy ( $p>$ $0.05)$. After chemotherapy courses; distress degree of concentration, appearance, outlook and fatigue were not different in two groups. Better sleeping quality $(\mathrm{p}=0.05)$, appetite $(\mathrm{p}=0.003)$, and mood $(p=0.03)$ were declared in group II than that of gro- up I after chemotherapy (Table 6).

There were no serious side effects in either group. Twenty-six side effects which may be attributed to the both of the drugs were observed in 24 (14 group I; 10 group II) of 70 courses. These were constipation, mild headache and dryness of mouth. There was no statistical difference between groups in respect of occurrence of side effects.

\section{DISCUSSION}

During last decades significant progress has been made in pharmacological treatment of childhood malignancy. This progress is associated with considerable increase in toxicity and complications. Nausea and vomiting are among the most distressing and debilitating side effects of chemotherapeutics.

Chemotherapy induced nausea and vomiting have two components. First is pharmacologically induced component which varies according to intrinsic

Table 5. Control of emesis according to duration of chemotherapy

\begin{tabular}{|c|c|c|c|c|}
\hline \multirow[t]{2}{*}{ EMESis } & \multicolumn{2}{|c|}{ Duration $<3$ days* } & \multicolumn{2}{|c|}{ Duration $\geq 3$ days ${ }^{\star \star}$} \\
\hline & Group I & Group II & Group I & Group II \\
\hline Complete response (SS.0) & 7 (25\%) & $15(60 \%)$ & $1(12 \%)$ & $4(45 \%)$ \\
\hline Partial/ No response (SS. 1-3) & $21(75 \%)$ & $10(40 \%)$ & 7 (88\%) & 5 (55\%) \\
\hline TOTAL & 28 & 25 & 8 & 9 \\
\hline
\end{tabular}


Table 6. Quality of life according to antiemetic therapy group

\begin{tabular}{|c|c|c|c|c|}
\hline & & & & \\
\hline & Group I & Group II & Group I & Group II \\
\hline Activity & 22 (61\%) & 28 (82\%) & 14 (39\%) & $6(18 \%)$ \\
\hline Sleeping * & 27 (75\%) & 32 (94\%) & 9 (25\%) & 2 (6\%) \\
\hline Appetite ** & 15 (42\%) & 27 (79\%) & 21 (58\%) & 7 (21\%) \\
\hline Emotion $^{\star \star \star}$ & 20 (55\%) & 28 (82\%) & 16 (45\%) & $6(18 \%)$ \\
\hline${ }^{*} p=0.05$ & ${ }^{* *} p=0.003$ & & & \\
\hline
\end{tabular}

emetic potential, dose, route and rate of administration of the drug. ${ }^{2,14}$ The other is psychological component. Being treated for cancer has emotional and psychological implications on patients which is more obvious on adolescent and female patients. ${ }^{2,14}$ Emotional factors not only initiate anticipatory emesis but also amplify post-chemotherapy emesis. ${ }^{2,4,5,14-17}$ Psychological factors induce emesis through higher cortical centers input which conducted directly into "central pattern generator" formerly named as vomiting center. Chemotherapeutics induce emetic reflex by causing release neuroactive agents such as 5-hydroxytryptamine (5-HT) from enterochromaffin cells of gastrointestinal tract. These agents interact with vagal efferent which conducted the emetic reflex to firstly nucleus tractus solitarius and area postrema (chemoreceptor trigger zone), and then "central pattern generator". Chemotherapeutics can interact directly area postrema, since blood brain barrier is permeable in this area. There is high concentration of dopamine-2 and 5-hydroxytryptamine-3 (5-HT3) receptors in the nucleus tractus solitarius. Histamine-H1, muscarinic acetylcholine, dopamine-2, neurokinin-1 and 5-HT3 receptors have been identified abundantly in "central pattern generator". ${ }^{25,14}$ Antiemetic drugs act with antagonizing this emetogenic receptor. Although considerable advances have been made in antiemetic therapy especially by using 5-HT3 antagonists, emesis is still most frightening problem for children receiving chemotherapy. ${ }^{2,3,514}$ Indeed, each chemotherapy course causes state anxiety like an invasive dental and medical procedure. Hos- pitalization and being received chemotherapy, expectation for side effects, and unpleasant experiences bringing from the former course are reason for the distress and anxiety. Anxiety and distress can powerfully amplify chemotherapy induced nausea and vomiting, even initiate emesis..$^{2,415-17}$ Psychological component of nausea and vomiting is highly resistant to antiemetic drugs. Some psychological intervention which control emotional factors may reduce emesis. It has been reported that acupuncture, aqua stimulation, muscle relaxation, hypnotherapy are effective adjuvant intervention for control of both anticipatory and post-chemotherapy emesis. ${ }^{15-20}$ It has been showed that severity of chemotherapy induced emesis was decreased when the chemotherapeutics were given during sleep. ${ }^{21}$ Several mechanisms including through which these intervention may have exerted its effects have been proposed. Patient expectation of benefit, attentional diversion, reduction of stress and anxiety, and physiological sedation are among these mechanisms. ${ }^{15,18,20}$ It has been suggested that physiological sedation may have antiemetic effect because of the biochemical changes that it produces. ${ }^{22}$

It seems to appropriate to think that premedication before chemotherapy by using a sedative agent may contribute to control of emesis. Drugs that moderate anxiety and distress such as lorazepam have been used with success in emesis in adult cancer patients. ${ }^{23}$ In the late 1980s, combination of antihistaminics (generally diphenhydramine) with metoclopramide plus methylprednisolon was shown to be more efficacious to prevent nausea and vomiting. ${ }^{24}$ 
However there is not enough experience on using hydroxyzine in conjunction with the 5HT3 receptors.

Hydroxyzine is a first generation $\mathrm{H} 1$ receptor antagonist which acts also as a lesser extent at muscarinic and 5 HT2 receptors with even less binding to dopamin-2 receptor. It is widely used for skin allergies. Like the other first generation antihistaminic drugs, it causes central nervous system depression. It has been showed that hydroxyzine possess a mild anxiolytic, sedative, hypnotic and weak antiemetic properties. ${ }^{25,26}$ Mood elevating and energizing effect of the hydroxyzine has been well known for a long time. ${ }^{27}$ Hydroxyzine may also be used for reducing anxiety in children who become distressed when faced with unpleasant, fear provoking situation. It is a popular drug in pediatric conscious sedation that necessary for invasive dental and medical procedures. ${ }^{26,28,29}$ Oral hydroxizine is adsorbed rapidly, sedative effect started within 15 to 30 minute. Its half life is 12-20 hours and it can cross the blood brain barrier. Hydroxyzine tolerates well in average therapeutic doses. A single or repeated dose of $1 \mathrm{mg} / \mathrm{kg}$ orally, a few hours before such procedures is usually effective to alleviate anxiety and get the child sedate. ${ }^{25,26}$ It seems to appropriate to think that hydroxyzine may be used for premedication of unpleasant chemotherapy course. It may contribute to the control of emesis by alleviating the distress of the child. Its additional weak antiemetic properties may be of value in reducing vomiting.

We could find only one report investigating the effect of hydroxyzine combined with 5-HT3 blockers. The study has been conducted on adult cancer patients and the hydroxyzine has been combined with granisetron instead of steroid. Authors concluded that steroid could not be administered some patients such as cases with peptic ulcer, and they offered hydroxyzine because of its weak antiemetic effect. In this study, the combination of granisetron and hydroxyzine significantly increased the control of acute emesis and provided a better quality of life than that of granisetron alone. ${ }^{30}$

We choose hydroxyzine owing to especially its sedative and anxiolytic effect. The drug is began to patients before chemotherapy and continued during the course. We observed that the complete and major control rate of acute emesis in courses used on- dansetron plus hydroxyzine was significantly higher than that of group using only ondansetron. The effect of combination antiemetic therapy was more obvious in female, and in adolescent patients who are emotionally more labile. Furthermore appetite, sleeping quality, activity, mood and quality of life of were better in patients treated with hydroxyzine and ondansetron combination.

In conclusion, hydroxyzine may enhance the activity of ondansetron in controlling acute emesis through its sedative-anxiolytic effect and weak antiemetic effect. Combination of hydroxyzine with ondansetron provided also a better performance and lesser symptom distress and therefore contributes to improvement in quality of life.

A preliminary form of this study has been presented in the poster discussion session during the XXXVI. SIOP Meeting, September 2004, Oslo, Norway

\section{REFERENCES}

1. Bryant R. Managing side effects of childhood cancer treatment. J Pediatr Nurs 18:113-125; 2003.

2. Antonarakis ES, Hain RDW. Nausea and vomiting associated with cancer chemotherapy: drug management in theory and in practice. Arch Dis Child 89: 877 880, 2004.

3. Oo TH, Hesketh PJ. Drug insight: new antiemetics in the management of chemotherapy induced nausea and vomiting. Nat Clin Pract Oncol 2: 196-201, 2005.

4. LeBaron S, Zelter LK, LeBaron C, et al. Chemotherapy side effects in pediatric oncology patients: drugs, age, and sex as risk factors. Med Pediatr Oncol 16: 263268, 1998.

5. Hesketh PJ. Defining emogenicity of cancer chemotherapy regimens: relevance to clinical practice. Oncologist 4: 191-196, 1999.

6. Skoup M. A comparison of two dose levels of granisetron in patients receiving high dose cisplatin. Eur J Cancer 26 (Suppl.1): 15-19, 1990.

7. Smith IE. A comparison of two dose levels of granisetron in patients receiving moderately emetogenic cytostatic chemotherapy. Eur J Cancer 26 (suppl 1): 19-23, 1990.

8. Lansky SB, List MA, Lansky LL, et al. The measurement of performance in childhood cancer patients. Cancer 60: 1651-56, 1987.

9. McCorcle R, Cooley M, Shea JA. A user's manual for the Symptom Distress Scale. Philadelphia, University of Pennsylvania- National Institute of Nursing Research, 1998 
10. McCorcle R, Young K. Development of a symptom distress scale. Cancer Nurs 5: 373-378, 1978.

11. Sarna L. Correlates of symptom distress in women with lung cancer. Cancer Pract 1: 21-28, 1993.

12. Hinds PS, Quargnenti A, Bush AJ, et al. An evaluation of the impact of a self-care coping intervention on psychological and clinical outcomes in adolescents with newly diagnosed cancer. Eur J Oncol Nurs 4: 617, 2000.

13. Ergun M. Bilimsel araştırmalarda bilgisayarla istatistik uygulamaları. Ankara, Ocak yayınları, 1995.

14. Hesketh PJ. Chemotherapy-induced nausea and vomiting. N Engl J Med 358: 2482-2494, 2008.

15. Burish TG, Carey MP, Kozely MG, Greco FA. Conditioned side effects induced by cancer chemotherapy: prevention through behavioral treatment. J Consult Clin Psychol 55: 42-48,1987.

16. Patenaude AF, Kupst MJ. Psychosocial functioning in pediatric cancer. J Pediatr Psychol 30: 9-27, 2005.

17. Tyc VL, Mulhern RK, Barclay DB, et al. Variables associated with anticipatory nausea and vomiting in pediatric cancer patients receiving ondansetron antiemetic. $J$ Pediatr Psychol 22: 45-58,1997.

18. Redd $\mathrm{WH}$, Jacobsen PB, Die-Trill M, et al. Cognitive/Attentional Distraction in the control of conditioned nausea in pediatric cancer patients receiving chemotherapy. J Consult Clin Psychol 55: 391-395, 1987.

19. Reindl TK, Geilen W, Hartman R, et al. Acupuncture against chemotherapy-induced nausea and vomiting in pediatric oncology. Support Care Cancer 14: 172176, 2006.

20. Zeltzer LK, Dolgin MJ, LeBaron S, LeBaron C. A randomized, controlled study of behavioral intervention for chemotherapy distress in children with cancer. Pediatrics 88: 34-42, 1991.

21. Ortega-Dominguez L, Cubedo-Cervera R, Cortes-Funes H, Diaz Gallego E. Sleep protects against chemotherapy induced emesis. Cancer 77: 1566-1570, 1996.

22. BorisonHL, McCarthy LE. Neuropharmacology of chemotherapy-induced emesis. Drugs 25(suppl 1): 8-17, 1983.

23. Laszlo J, Clark RA, Hanson DC, et al. Lorazepam in cancer patients treated with cisplatin: a drug having antiemetic, amnesic and anxiolytic effects. J Clin Oncol 3: 864-869, 1985.

24. Roila F, Tonato M, Basurto C, et al. Protection from nausea and vomiting cisplatin-treated patients: high dose metoclopramide combined with methylprednisolone vs metoclopramide combined with dexamethasone and diphenhydramine: a study of Italian Oncology for Clinical Research. J Clin Oncol 7: 1693-1700, 1989.
25. Brown NJ, Roberts LJ. Histamin, bradykinin and their antagonists. In: Goodman Gilman's The Pharmacological Basis of Therapeutics. Hardman JG, Limbird LE, Gilman GA (eds). London, McGraw-Hil, 2001: 645-57.

26. Dulcan MK, Bregman JD, Weller EB, Weller RA. Treatment of Childhood and adolescent disorders. In: Textbook of Psychoparmacology. Schatzberg AF, Nemeroff CB, (eds). Washington, American Psychiatric Press Inc, 1995: 669-706.

27. Dolan CM. Management of emotional disturbances: Use of hydroxyzine in general practice. Calif Med 88: 443-444, 1958.

28. Cigada M, Pezzi A, Di Mauro P, et al. Sedation in the critically ill ventilated patient: possible role of enteral drugs. Intensive Care Med 31: 482-486, 2005.

29. Faytrouny M, Okte Z, Kucukyavuz Z. Comparison of two different dosages of hydroxyzine for sedation in the pediatric dental patient. Int J Paediatr Dent 17: 378-382, 2007.

30. Tsukuda M, Furukawa S, Kokatsu T, et al. Comparison of granisetron alone and granisetron plus hydroxyzine hydrochloride for prophylactic treatment of emesis induced by cisplatin chemotherapy. Eur J Cancer 31A: 1647-1649, 1995.

\section{Correspondence}

Dr. Nilgün KURUCU

Ankara Onkoloji Eğitim ve Araştırma Hastanesi

Urankent Ek Binası

Çocuk Onkolojisi Kliniği

Mehmet Akif Ersoy Mahallesi

Yeni Mahalle, ANKARA / TURKEY

Tel: (+90.462) 3360909

Fax: (+90.462) 3344917

e-mail: nlgnkrc@gmail.com 